\title{
The Impact of Personalized Engagement with Customers and Efficient Stock Management Software Systems on Customer Service at a Clothing Retailer in Cape Town, South Africa
}

\author{
Virimai Victor Mugobo \\ Department of Retail Business Management, Faculty of Business, Cape Peninsula University of Technology, South Africa \\ Email:mugobov@cput.ac.za \\ Marina Giacoma Baschiera \\ Department of Retail Business Management Faculty of Business, Cape Peninsula University of Technology, South Africa \\ Email: marinabaschiera@gmail.com
}

\section{Doi:10.5901/mjss.2015.v6n1p40}

\section{Abstract}

\begin{abstract}
In today's day and age, technology is a major game changer in the retail industry. Parallel variables were explored concurrently to establish their simultaneous impact on customer service. The study sought to determine the impact personalized engagement on customers, as well as the impact that efficient stock management software systems on customers using a clothing retailer in Cape Town as a case study. The study also sought to explore the challenges and opportunities that retailers face when they use technology in the customer service delivery process. The methodology used in this study involved a combination of quantitative and qualitative research. The study consisted of 55 respondents specific to the chosen location. Based on the study, retailer's still face challenges of incorporating technology to improve customer service, on an "Omnichannel" level. Technological advancements would include handheld devices operated by sales assistants and/or customers, acquiring quick and accurate product information; interactive stand-alone digital touch-screen displays allowing customers to access in store and online product and service information; mobile apps and online store fully synchronised with the retailers stock software systems, virtual personalized models and customized online 'wardrobe', all connected by intelligent technological in store infrastructure. Retailers have many opportunities in the form of implementing rapidly developing technology throughout physical and online stores to create a hybrid leading retail platform where virtual meets physical shopping, under one roof. The study concludes by recommending that retailers should move off out-dated systems currently employed (i.e. the legacy systems), onto innovative stock software systems. Thus, bringing current inventory software systems up to a level where they are able to interface with technologies mentioned in this study, to improve customer satisfaction.
\end{abstract}

Keywords: personalized engagement; inventory software systems; interface; customer satisfaction; Omni-channel

\section{Introduction}

The retail industry faces unprecedented challenges as technology advancements continue to accelerate, coupled with the rising expectations of today's empowered consumer. The boundary between physical and virtual retailing has become a blur with a need for more sophisticated products, services, value and environment. Retailers are constantly developing cutting-edge technological strategies and software systems to keep up with the advances, while staying connected to the customer (Albers, 2013). According to Motorola Inc. (2008:2) a new way of thinking is required to address these issues. The researcher sought to establish the impact of personalized engagement with customers and inventory management systems on customer service in the retail industry. Vast innovation is crucial to achieve excellence in technologically savvy customer service and satisfaction. Hauss et al. (2012) note that investments in technology that is able to mobilize sales associates will greatly improve customer satisfaction. Immediate product information can be communicated from sales associates to customers, through devices connected to intelligent technological store infrastructure. Alternatively, customers will be able to gather product information via digital touchscreen displays in store, eliminating the need for sales associates. It is essential for retailers to take on an aggressive approach at adapting and becoming comfortable with "Omni-channel technologies" (multi-channel retailing, concentrated on creating a seamless approach to customer experiences through all available shopping channels), focused on competitive advantage and survival. Hauss et al. (2012) further mentions how fickle and unpredictable consumers have become, more so with the extensive choice of 
retailers. Due to these conditions, it became evident to the researcher that development of stock management software systems, in conjunction with the training of sales associates on efficient utility of software, is fundamental to combat customer dissatisfaction and complaints. The researcher hoped to, and has developed intellectual insight on the expectations of customers, the efforts of retailers and reality.

\section{The Research Problem}

The main problem faced by the specific clothing retailer lies in providing customers with quick, efficient and accurate product information. Sales assistants are required to check time-consuming POS systems when seeking product information requested by customers. Consequentially, the long-haul process taints customers' shopping experiences. Retailers require flexible, easy and smart inventory software platforms accessible to customers. Current technical systems employed by the clothing retailer specific to this study, are outdated and inefficient time wasters. A basic approach has been taken to develop the selected clothing retailer's online store, which is characterized by the lack of interaction or fun created when visiting the website. Customers are able to "get the job done" and purchase items they desire, however it does not go the extra mile to help look after customers. Technology channels implemented by this retailer do not enhance the company offerings in terms of product or services, only performing the basic functionality of the online system.

\section{Literature Review}

\subsection{The Concept of Personalized Engagement with Customers}

Brodie et al. (20414) postulate that customer engagement (CE) in today's highly dynamic and interactive business environment, personalized engagement with customers is a crucial ingredient to effective and efficient customer service. Brodie et al. (20414) examine the word "engagement" in terms of social science, marketing and management concepts, as well as evaluating the broader significance of "involvement" and "participation". Haid \& Sims (2009:17) outline the link between employees engaging with customers, resulting in increased customer loyalty and satisfaction. Consequently, engaged staff having a positive attitude towards the organization and its stakeholders will ultimately result in increased customer satisfaction. Furthermore, Haid \& Sims (2009:7) state that employee-organization alignment is a driving force of performance, measured in terms of "customer satisfaction, innovation, profitability, productivity, loyalty and quality". These key measures are a result of employees engaging with customers.

\subsection{The Impact of Personalized Engagement On Customer Service}

According to the Bell (2013) $63 \%$ of customers who have had a positive experience with a sales associate will purchase from that store again and $58 \%$ of customers who had a negative experience will not return, with $70 \%$ of customers warning others not to use that same company. Mohr and Bitner (2000) examine how perceived employee effort and customer service has a strong positive or negative impact on customer satisfaction. Kumar et al. (2014) highlight the prominence of valuing customer engagement correctly, avoiding the under- or over-evaluation of customers. According to Long (n.d), "efficient customer service departments seek to solve problems as they occur, and, if possible, prevent them in the first place." Treating customers with respect and going the extra mile than expected can keep customers returning, forming a loyal customer base. Long (nd) corroborates the above authors when he asserts that aside form apparent external benefits, good customer service pertains internal benefits by capitalizing on customer suggestions, creating opportunity and leading to innovation.

\subsection{The Impact of Efficient Stock Management Software Systems On Customer Service}

Telerik (2014) defines customer segmentation as the first step in the personalized customer engagement process. Understanding the needs of customer categories is important and necessary in order to deliver a personal experience. Telerik (2014) elucidates that correct strategic segmentation positively impacts brand loyalty. According to Hildebrand (2014), once the appropriate technological infrastructure is in place, the process can successfully begin. Hildebrand (2014) elucidates the notion of customers making the rules, owing to technology as the game changer. It is imperative to accept that retailers are currently experiencing a profound paradigm shift in the way they interact with customers. Donston (2010) explains that good customer service is a key element for customer retention, as well as attracting new 
customers. Furthermore, retailers are impotent against highly connected consumers. One bad customer experience may go viral, potentially harming a retailer's image. Cisco (n.d.) identifies elements of an organization that could be enhanced through digital and interactive screens. The intention rests in enhancing store environments to provide customers with a visual, interactive and immersive shopping experience, as well as improved marketing and merchandising effectiveness through digital displays (Cisco, n.d.). Interactive digital display screens include various channels of communication. The desired end-goals would ideally comprise of providing in store face-to-face customer consultation with relevant, accurate and useful product information; improving employee training and create new and more exciting job descriptions; increase operational efficiency; as well as migrating the physical store to an online store and vice versus, ensuring the golden thread rule of consistency. Retailers aim to go through communication channels comprising of video, voice and online screen sharing between stores (ibid).

\subsection{The Role of Stock Management Systems in a Retail Environment}

DMS Retail (2013) debates the evolution of the traditional 4P's in marketing (product, price, promotion and place), and the development to the 6P's today. Added elements to the marketing pillars include People and "Pixel" or technology. The word Pixel was selected in order to remain in compliance with the "P" factor. Technology is playing an increasingly important role in the retail environment and contributes greatly to the success of a retailer. Moreover, retailers not willing to embrace technology at the forefront continue to fight a losing battle and are doomed to fail. According to Ingram (2014), fundamental tools required in running a competitive business includes security technology; Point-of-Sales (POS) interface systems, as well as RFID (radio-frequency identification technology) readers able to provide instant product information to customers. Olenski (2013) points out that the implementation of technological advancements by retailers, provides added value to customers. Retailers are simplifying online and in store check out, as well as developing and incorporating mobile apps containing catalogs, look books, customization, online shopping and support. Furthermore, large organizations are investing billions of dollars developing 'real-life shopping experience(s)' for customers who wish to get a 360-degree store view and product display whilst shopping online, as satisfied customers are reflected in an increased bottom line (ibid).

\subsection{Benefits of Advanced Inventory Software Technologies for Companies}

Dräger (2013) evaluates the benefits of technology from a customer's point of view. This is relevant to the researcher's area of study, as it is based on the outcome of good customer service. A customer's shopping experience is most pleasurable when they find the right size, colour, style, and so forth. Technologies such as the innovative idea of interactive RFID's provides visibility into the inventory system by automatically identifying and tracking merchandise, ensuring retailers and customers are able to locate desired items quickly. Dräger (2014) further notes the possibility of equipping change rooms with RFID scanners, providing additional product information, sharing pictures and product information on social media, and even calling for assistance. Albers (2013) opines that direct touch has been lost between customers and retailers, and it is therefore essential for retailers to explore new avenues to rebuild their relationship with their customers. Albers (2013) emphasizes the necessity for retailers to reinvent themselves and keep up with the fundamental shift in the growth of technology. The world of social media undoubtedly provides a platform for retailers and customers to interact outside of traditional boundaries. Overall customer satisfaction will increase through the usage of technology to interactively engage with customers. The benefits are immense for both parties, including saving time, improving efficiency and adding fun to the shopping experience.

\subsection{Integrated Technical Software Advancements and Personal Engagement Strategies to Maintain a Satisfied Customer Shopping Experience}

Garrett (2013) states that traditionally, retailers engaged with customers on a first name basis and in the contemporary times, retailers are attempting to engage customers via personalised social media platforms (Garret, 2013). Platforms for engagement include customized mobile apps, emails and loyalty programs, all in an effort to bring about a sense of personal engagement. Garrett (2013) further states that much as physical stores continuing to generate the highest profits, it is important for retailers to combat old systems of "show rooming" and move towards customer centric Omnichannel shopping experiences. In such channels, real-time information is provided; assisting customers' purchasing decisions, with the assistance of real-time data accessible by sales associates (ibid). The retailer that was used in this study makes use of the available technological resources which incorporates supply chain (stock) management systems. 


\section{Research Methodology}

The researchers collected data through a combination of quantitative and qualitative research. Data was collected in the form of questionnaires and semi-structured interviews. Quantitative research was executed using a using a questionnaires as the data collection instrument. The questionnaires consisted of yes/no questions and multiple choice questions. Qualitative research was conducted using semi-structured interviews using questions that were open-ended. The open-ended questions were used to collect information not covered by the questionnaire and they encouraged respondents to provide their opinion regarding opportunities and challenges retailers face in delivering satisfying customer service. The researchers completed 55 questionnaires from 55 different respondents. Semi-structured interviews took place with 13 of the 55 respondents. The researchers conducted field research to observe the natural environment of where the questions are embedded. Major questions can be answered through verbal and non-verbal communication. Interpretive and descriptive research methods were used by the researchers when they analyzed interview responses. Elliot et al (2005: 149) describes descriptive data analyses as identifying the kinds or varieties in which the phenomena appears, and the aspects unique to the phenomena. Elliot et al (2005: 149) describes interpretative data analysis as identifying the reasons why the phenomena comes about, and how the challenges and opportunities unfold over time. The analysis is illustrated in the form of graphs, tables and descriptions clearly explaining the interpretation and recommendations. Bielat (2005) suggests that empirical research will be useful, used together with descriptive information or findings. Empirical research assisted the researcher in proving technological variables affect customer services, and evidently, customer (dis)satisfaction. All the research techniques were used in conjunction with each other, in order to gather the most accurate observations and data findings.

\section{Findings and Discussion}

This section discusses the finding of this study.

Figure 1: Profile of the age groups of the respondents at the selected clothing retailer

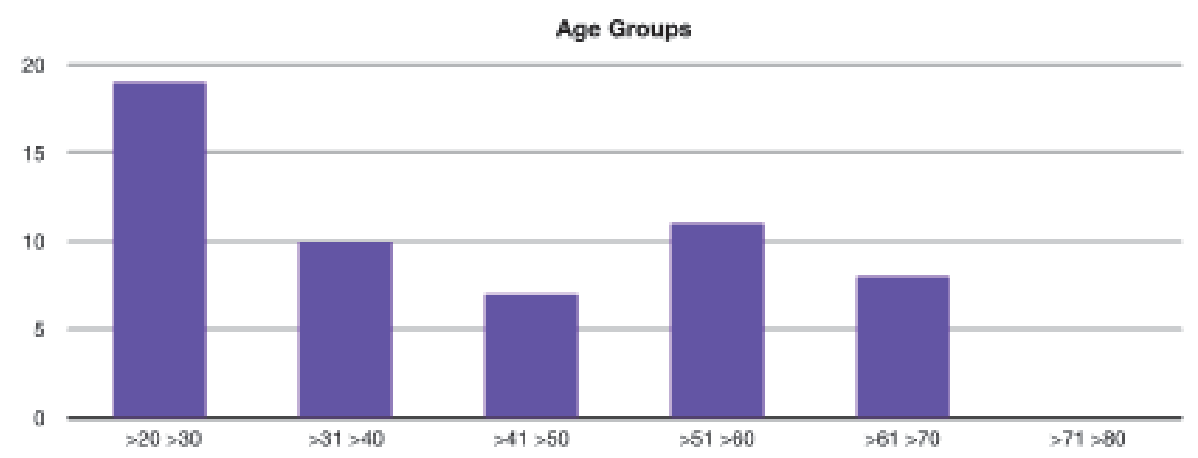

According to Figure 1 above, a considerable number of respondents are among the young adult population and the more mature adults who are approaching retirement.

Table 1: Gender

\begin{tabular}{ccc}
\hline Gender & Total & Percentage Weighting \\
Male & 20 & $36 \%$ \\
Female & 35 & $64 \%$ \\
Total & 55 & $100 \%$ \\
\hline
\end{tabular}

According to Table 1 above, $64 \%$ of respondents were female and $36 \%$ were male. It is clear that the majority of the respondents were female and this most probably indicates the gender composition of the market. 
Table 2: Valued advice from assistant

\begin{tabular}{|c|c|c|}
\hline Response & Frequency & $\%$ \\
\hline Yes & 43 & 78 \\
\hline No & 7 & 22 \\
\hline Total & 50 & 100 \\
\hline
\end{tabular}

Table 3: Advice on complimentary products

\begin{tabular}{|c|c|c|}
\hline Response & Frequency & $\%$ \\
\hline Yes & 43 & 78 \\
\hline No & 7 & 22 \\
\hline Total & 50 & 100 \\
\hline
\end{tabular}

Table 2 and Table 3 above show that 78\% of respondents value general and specific advice from assistants.

Table 4: Importance of customer service

\begin{tabular}{|c|c|c|}
\hline Response & Frequency & $\%$ \\
\hline Yes & 55 & 100 \\
\hline No & 0 & 0 \\
\hline Total & 55 & 100 \\
\hline
\end{tabular}

Table 5: Stop visits at unpleasant retailer

\begin{tabular}{|c|c|c|}
\hline Response & Frequency & $\%$ \\
\hline Yes & 46 & 83 \\
\hline No & 9 & 17 \\
\hline Total & 55 & 100 \\
\hline
\end{tabular}

Table 6: Update social media status on bad service

\begin{tabular}{|c|c|c|}
\hline Response & Frequency & $\%$ \\
\hline Yes & 37 & 67 \\
\hline No & 18 & 33 \\
\hline Total & 55 & 100 \\
\hline
\end{tabular}

Table 4 above illustrates a unanimous agreement that customer service is important, with $83 \%$ of respondents from Table 5 agreeing they would not return to an unpleasant retailer, and $67 \%$ of respondents would update their social media status on bad service, as shown in Table 6.

Table 7: Customer knowledge of in-store inventory systems

\begin{tabular}{|c|c|c|}
\hline Response & Frequency & $\%$ \\
\hline Yes & 15 & 28 \\
\hline No & 40 & 72 \\
\hline Total & 55 & 100 \\
\hline
\end{tabular}

Table 8: Use of customized mobile store apps

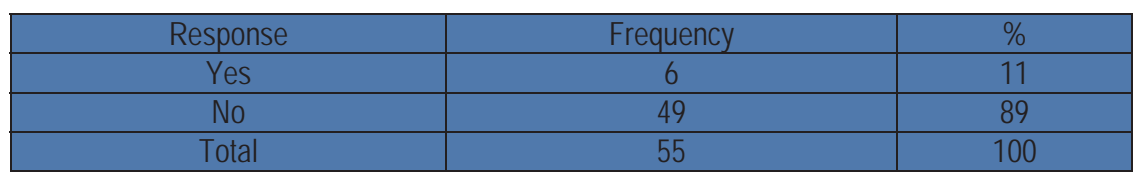


Table 9: Interactive screens to improve shopping experience

\begin{tabular}{|c|c|c|}
\hline Response & Frequency & $\%$ \\
\hline Yes & 46 & 83 \\
\hline No & 9 & 17 \\
\hline Total & 55 & 100 \\
\hline
\end{tabular}

According to Table 7 above, $72 \%$ of respondents do not possess knowledge of in-store inventory systems and Table 8 above shows that a mere $11 \%$ of respondents make use of customized mobile store apps. Table 9 above confirms that $83 \%$ of respondents choose in store interactive display screens to gain product information.

According to Table 10 below, all of the respondents have a need for immediate product information. Table 11 below shows that $94 \%$ of respondents place a heavy weighting on the need for product information without sifting through individual items.

Table 10: Need for immediate product information

\begin{tabular}{|c|c|c|}
\hline Response & Frequency & $\%$ \\
\hline Yes & 55 & 100 \\
\hline No & 0 & 0 \\
\hline Total & 55 & 100 \\
\hline
\end{tabular}

Table 11: View available stock, without sifting through individual items

\begin{tabular}{|c|c|c|}
\hline Response & Frequency & $\%$ \\
\hline Yes & 52 & 94 \\
\hline No & 3 & 6 \\
\hline Total & 55 & 100 \\
\hline
\end{tabular}

Table 12 and 14 below demonstrates that the majority of respondents have a strong feeling towards sales associates carrying handheld devices to provide immediate product information, as well as updated/advanced in store technology.

Table 12: Need for handheld devices used by sales associates in store

\begin{tabular}{|c|c|c|}
\hline Response & Frequency & $\%$ \\
\hline Yes & 49 & 89 \\
\hline No & 6 & 11 \\
\hline Total & 55 & 100 \\
\hline
\end{tabular}

Table 13: Appreciation of the services of personal shopping assistants

\begin{tabular}{|c|c|c|}
\hline Response & Frequency & $\%$ \\
\hline Yes & 24 & 44 \\
\hline No & 31 & 56 \\
\hline Total & 55 & 100 \\
\hline
\end{tabular}

Table 14: Need for in store technological upgrades/advancements

\begin{tabular}{|c|c|c|}
\hline Response & Frequency & $\%$ \\
\hline Yes & 52 & 94 \\
\hline No & 3 & 6 \\
\hline Total & 55 & 100 \\
\hline
\end{tabular}


Table 15: Daily usage of social media platforms

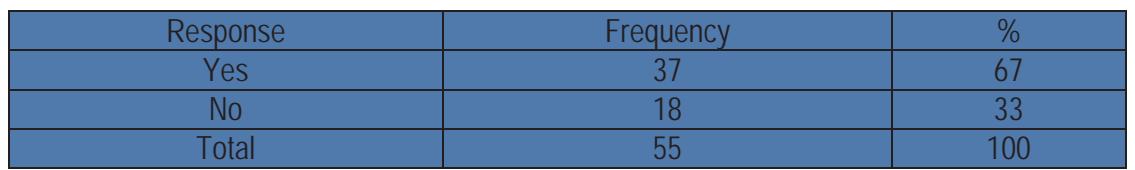

According to Table 13, the majority of the respondents appreciate the services offered by personal assistance. Finally, Table 15 above confirms that $67 \%$ of respondents use social media daily. This clearly shows that social media has become an important communication channel for consumers.

Overall, Table 3, 4, and 5 are highly rated in favour of personal engagement, confirming the need for human interaction or personalized engagement. Table 9 and 14 assert the need for in store technological upgrades and advancements for increased customer satisfaction.

Figure 2: Types of social media used daily

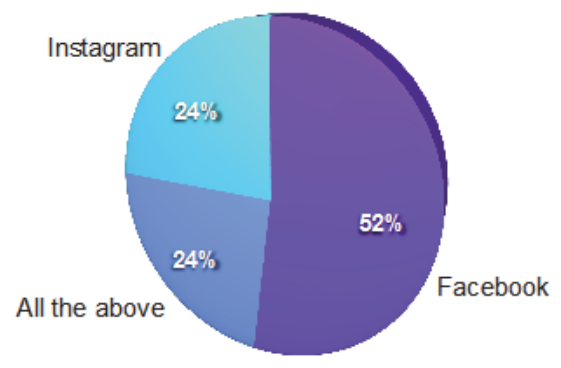

Figure 2 above clearly demonstrates the majority of the respondents use social media daily and that Facebook is the most popular social media platform.

Figure 3: Retail systems understood by customers

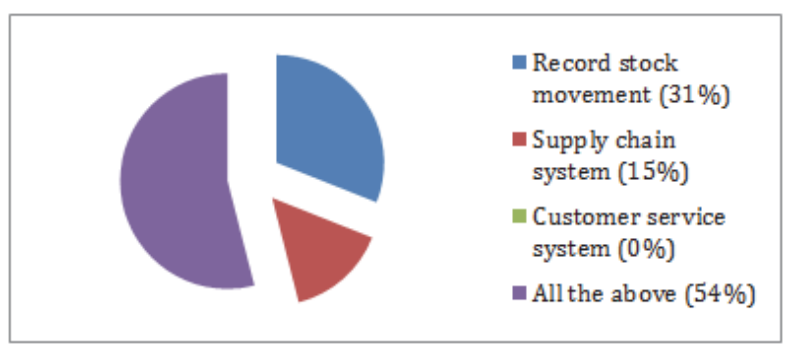

Figure 3 above shows customers understand most of the technological systems used by retailers. The majority ( $54 \%$ of the respondents acknowledged that they understand all the technological systems used by retailers.)

The researchers were also able to identify main and sub-trends derived from qualitative research conducted during the study. Main trends include the need for immediate and accurate product information; efficient self-service stations; integrated and transparent systems across retail store outlets; as well as high value placed on well trained, knowledgeable and efficient customer service.

Sub-trends ranged between mixed emotions based on the level personal shopping assistance given by sales associates; product tracking systems including digital in store maps that direct customers to specific points in store; efficient, quick, easy and smart shopping experiences; as well as virtual and/or tri dimensional concepts for product(s) customization. Based on the above trends, the researchers were able to deduce that customers prefer sourcing product information from a self-service point, rather than conversing with an assistant.

While conducting the qualitative study, the researchers observed customers' behaviour and interaction with technology. It was apparent that technology enables the user to control a private life within their device, without the need for physical human interaction. The researchers were therefore able to conclude that the industry faces a challenge of 
bridging the gap between customers wanting private space and the need for human interaction.

\section{Recommendations}

Based on the findings, the researchers came up with a number of recommendations. It is more than apparent that respondents place high value on customer service. Retailers are therefore recommended to encourage sales associates to offer assistance to every customer in store. Retailers are recommended to provide sales associates with a high standard of training to ensure customer satisfaction. The researchers further recommend the interlinking of face-to-face customer service with technology-based customer service, allowing for a physical and virtual interface connection, aiming to meet customers on their level. Retailers are also strongly recommended to streamline the service provided, parallel with the march forward of innovative consumers coupled with their ever high expectations. Customers perceive a shopping experience to be negative or positive according to the stimuli they face during the time spent in the store environment. Therefore, the researchers recommend that retailers should provide customers with easy access to product information, encouraging a touch of a button interaction during a shopping experience, which is vital for survival in the near future.

The researchers observed the shopping behavior of consumers and concluded that customers do not enjoy investing time into inefficient causes. Thus, it is recommended that retailers implement interactive digital display screens located in store and in the changing rooms, assisting customers in finding their sizes, preferred colour and styles, track orders, as well as selecting customized virtual models. A map identifying where customers are able to locate each item in the store will provide an efficient shopping experience, increasing customer satisfaction level. Respondents expressed their desire for efficient, quick, easy and smart shopping experiences. Based on these findings, the researchers recommendation the installation of interactive digital display screens connected online by intelligent in store infrastructure. Further recommendations conceptualized by the researchers include customized virtual models, which allow customers to develop a personalized character. The idea behind virtual customized models is to create a convenient space where customers can try on clothing items on their virtual model. The virtual fitting room provides a space for customers to try on items, mix and match various pieces, all before purchasing. The preferred quick and easy avenue respondents seek will be fulfilled via this channel. The researchers also recommend that retailers should install small digital display screens, similar to RFID's, situated on the railing of each item variation. The product information displays (PIDs) should contain the SKUs price, the amount of SKUs available per size, and the sizes available on that particular railing. The researchers further recommend that this system aims to eliminate difficulty and effort customers are required to go through when sifting between items to find their size. According to the findings, the majority of respondents stated they would not return to a retailer if they had an unpleasant experience. The researchers therefore strongly recommend an intelligent technological in-store infrastructure development and implementation, which interconnects and shares detailed inventory system information across all platforms used in store to ensure customers receive accurate and up-to-date product information. The PIDs includes a barcode, which can be scanned with a mobile device. The barcode will give customers access to product information such as where the garment was made, fabrics used, wash and care instructions, the possibility of ordering the item online, and any extra information about campaigns or initiatives linked to that specific item. Additional product information would be accessible via mobile apps, interactive screens or sales associates equipped with Wi-Fi connected tablets for immediate product information. The researchers recommend that retailers develop userfriendly mobile apps designed in conjunction with popular platforms of social media boosts exposure of an organization, increasing the currently low usage of mobile apps, according to the findings. Suggestions include marketing and creating excitement around a campaign via social media platforms as an affordable and effective means of reaching a large audience. Customers remember more how they feel in any given situation. They are more likely to spread the word of an on going campaign that they have participating in. 'Hashtagging' intangible or tangible experiences could lead to national and international exposure, create unity and churn up excitement about a particular situation. Lastly, the researchers strongly recommend that retailers sync online and physical stores - this is a crucial objective not only to remain competitive, but for survival. Through the researchers' observation, it was evident that technology numbs customers and extra stimulation is required to draw customers' attention. The greater the degree of stimuli, the greater the response of customers will be.

\section{Conclusion and Implications}

Technology is a dynamic phenomenon that is continuously evolving. Information is easily accessible and constantly available. Customers have become more empowered as a result of the vast knowledge available at their fingertips. 
Customers possess soaring expectations of services and products provided by the industry, demanding satisfaction according to international standards. Retailers have reached a point of taking the leap of faith and biting the metaphorical technological apple in order to remain competitive and to ensure survival. Customers value well-trained, knowledgeable and efficient sales assistants, improving customer satisfaction. The overall findings of this study point out to the need for quick, accurate and detailed product information, which is readily available at the convenience of customers. Customers have a growing demand for access to necessary resources, with their shopping experience being impacted either negatively or positively, dependent on whether demands are met or not. Virtual shopping in a physical store environment assists customers in making purchasing decisions. Eliminating 'time wasters' such as fitting on clothing or waiting for any type of product information is essential for retailers to implement. Customers are becoming more and more demanding, with less patience. Brick-and-mortar retailers are cracking under the pressure of technology. In order for retailers remain competitive and in existence, the opportune moment has risen and now is the time to implement cutting-edge innovation. Retailers need to create an interactive, fun, dynamic, trendy and efficient shopping environment, attracting even those customers who perceive shopping to be unpleasant. The researcher concludes the study emphasizing the urgency for retailers to implement innovation in order to vastly improve customer satisfaction.

\section{Recommendations for Further Engagement of the Subject}

Technology is dynamic and ever changing. Cutting-edge devices and systems are continuously being developed and launched. Research in the field of technology is broad and constant, thus future studies are infinite. Important points for further study include how to synchronize physical stores with online stores to create a hybrid-shopping environment. Connecting the two worlds will bridge the gap, eliminating mistrust of online shopping perceived by many customers. Each area of innovation is relevant and requires attention in terms of thorough and efficient development. Future studies including selecting and focusing on specific areas of innovation mentioned in this study, including personalized virtual models; PIDs; and most importantly, an intelligent technological in store infrastructure. Upholding good customer service throughout the implementation process of specific technological advancements is another point that requires in depth study. Retailers should avoid the perception that implementing innovations in-store will eliminate the need for personalized engagement with customers. Human interaction forms a vital part in fulfilling need recognition and satisfaction. Customers enjoy the physical shopping experience either as a past time, professionally or other motives. The psychological aspect of in-store shopping experiences may also be a point of focus for future studies. One last point covers the psychological effects that may occur if retailers use technology to interact with customers, and the impact it may potentially have on future generations.

\section{References}

Albers, B. 2013. Retail's reinvention: technology's impact on today's supply chain. Gigaom Research. [online] Available at: http://research.gigaom.com/report/retails-reinvention-technologys-impact-on- todays-supply-chain/ [Accessed 28 April 2014]

Anonymous (n.d). Sample Acknowledgement Page. [online] Available at: http://www.valdosta.edu/academics/graduate-school/ documents/sample- acknowledgement-page.pdf [Accessed 7 May 2014]

Anonymous, n.d. Research Strategies: An Overview. [online] Available at: http://hccedl.cc.gatech.edu/documents/114_Fisk_ research\%20strategies\%20 2004.pdf [Accessed 8 may 2014]

Anonymous, 2009. The four main approaches. Alzheimer's Group. [online] Available at: http://www.alzheimer-europe.org/Research/ Understanding- dementia-research/Types-of-research/The-four-main-approaches [Accessed 8 May 2014]

Bell, A. 2013. Customer service hits the bottom line. Institute of Customer Service. http://www.instituteofcustomerservice.com/171113021/Customer- service-hits-the-bottom-line.html [27 August 2014]

Bielat, V. 2008. Identifying an empirical research article. [online] Available at: http://www.slideshare.net/wsuinst/identifying-an-empiricalresearch-article- presentation [Accessed 8 May 2014]

Brodie, R.J., Holleebeek, L.D., Jurić, B., llić, A. 2014. Customer Engagement

Conceptual Domain, Fundamental Propositions, and Implications for Research. JSR. [online] Available at: http://jsr.sagepub.com /content/14/3/252.short [Accessed 28 April 2014] Buzztime. 2013. 5 Benefits of in-venue digital signage. http://www.buzztimebusiness.com/smarts/benefits-digital-signage-venue/ [27 August 2014]

Chanthadavong, A. 2013. The two way impact of technology. RetailBiz [online] Available at: http://www.retailbiz.com.au/2013/09/23/ article/The-two- way-impact-of-technology/VMTGOQQSSV.html [Accessed 28 April 2014]

Chavie, R. 2014. How retailers can use technology to enhance customer experiences. The Business Journal. http://www.bizjournals.com /bizjournals/how-to/technology/2014/03/how-retailers-can-use-technology-to-enhance.html?page=all [27 August 2014]

Cisco. N.D. Cisco Digital Signs. Cisco. Available at: http://www.cisco.com/c/en/us/products/video/digital-media-manager/digital_ signs.html [28 August 2014] 
DMS Retail. 2013. Introducing the $6^{\text {th }}$ pillar of retail. http://www.dmsretail.com/6thp.htm [25 August 2014]

Donston, D. 2010. The Impact of Technology on Customer Service. eWeek. [online] Available at: http://www.eweek.com/c/a/lTManagement/The-Impact- of-Technology-on-Customer-Service/ [Accessed 21 April 2014]

Dräger, K. 2013. Do they see what you see? Benefits of RFID in fashion retail from a customer point of view. RFID

Arena. [online] Available at: http://www.rfidarena.com/2013/9/19/do-they-see-what-you-see-benefits-of- rfid-in-fashion-retail-from-acustomer-point-of-view.aspx [Accessed 8 May 2014]

Elliot, R and Timulak, L. 2005. Descriptive and interpretive approaches to qualitative research. A handbook of research methods for clinical and health psychology. [online] Available at: http://nideffer.net/classes/GCT_RPI_S14/readings/interpretive.pdf [8 May 2014]

Haid, M. \& Sims, J. 2009. Employee engagement, maximizing organizational performance. Right. [online] Available at: http://www.right.com/thought-leadership/research/employee-engagement---maximizing-organizational-performance.pdf [Accessed 28 April 2014]

Hauss, D. 2012. 14 Retail Executives Share Technology Predictions For 2013. Retail Touch Points. [online] Available at: http://www.retailtouchpoints.com/in-store-insights/2137-14-retail-executives- share-technology-predictions-for-2013 [Accessed 10 March 2014]

Hildebrand, V. 2014. Personalized customer engagement - how to get started. Customer Engagement Solutions. [online] Available at: http://www.clarisys.com/news-and-articles/415-personalized-customer- engagement-how-to-get-started [Accessed 8 May 2014]

Ingram, D. 2014. The technology needed to run a clothing store. Chron. [online] Available at: http://smallbusiness.chron.com/technologyneeded-run- clothing-store-10779.html [Accessed 8 May 2014]

Info Entrepreneurs (n.d). Stock control and inventory. http://www.infoentrepreneurs.org/en/guides/stock-control-and-inventory/ [25 August 2014]

Kim, Y.S. 2013. The Importance of Literature Review in Research Writing. Hub Pages. http://hubpages.com/hub/literature_review [25 August 2014]

Kumar, V., Aksoy, L., Donkers, B., Venkatesan, R., Wiesel, T., Tillmanns, S. 2014. Undervalued or Overvalued

Customers: Capturing Total Customer Engagement Value. Journal of Research (JSR). [online] Available at: http://jsr.sagepub.com/ content/ 13/3/297.short [Accessed 28 April 2014]

Long, N. n.d. The Impact of Good Customer Service in Small Business. Chron. http://smallbusiness.chron.com/impact-good-customerservice-small- business-2080.html [12 August 2014]

Mohr, L.A. \& Bitner, J. 1995. The role of employee effort in satisfaction with service transactions. Journal of Business

Research [online] Available at: http://www.sciencedirect.com/science/article/pii/014829639400049K [Accessed 27 April 2014]

Motorola, Inc. 2008. The next revolution in retail technology. [online] Available at: http://www.motorolasolutions.com/web/Business/ Solutions/_ChannelDetails/_Documents/static\%20files/FutureRetail_WP_0108(2).pdf [Accessed 10 March 2014]

Mukharji, P., Israelit, S., Faelli, F., Catfolis, T., Tsang, R. 2011. Ten ways to improve inventory management. Insights. Available at: http://www.bain.com/publications/articles/ten-ways-to-improve-your-inventory- management-wsj.aspx [27 August 2014]

Olenski, S. 2013. How retail brands are using technology to provide added value to consumers. http://www.forbes.com/sites/ steveolenski/2013/11/25/how-retail-brands-are-using-technology-to-provide-added-value-to-consumers/ [27 August 2014]

Scottsdale, A. 2012. Woolworths South Africa Selects JDA Software Solutions to Optimize its Retail Supply Chain.

JDA Software Group [online] Available at: http://www.jda.com/file_bin/pr/jda_wwsa_PR_final.pdf [Accessed 7 May 2014]

Telerik. 2014. Drive brand loyalty through personalized customer experience. Telerik Sitefinity. [online] Available at: http://www.sitefinity. $\mathrm{com} /$ solutions/personalize-content-for-customer-loyalty [Accessed 8 May 2014]

The Queensland University. 2014. Principles of good customer service.http://www.business.qld.gov.au/business/running/customerservice/improving- customer-service/customer-service-principles [25 August 2014] 